Virtual Mentor. April 2004, Volume 6, Number 4.

doi: 10.1001/virtualmentor.2004.6.4.cprl3-0404

Clinical Pearl

\title{
Prospects for Daily Nocturnal Hemodialysis (DNHD)
}

\section{Studies have shown that patients undergoing daily nocturnal hemodialysis have better medical results and lower overall health costs than patients treated with tradition dialysis.}

\author{
Christopher D. Hoy, MD
}

As our population ages, more people are developing chronic renal failure. It is predicted that 520000 people will require dialysis by 2010 [1]. Forty-four percent of patients with end-stage renal disease (ESRD) in 2001 were diabetics, and diabetes, too, is on the rise. In 2000, patients with ESRD comprised 0.7 percent of the Medicare population and consumed 6 percent (\$14 billion) of the Medicare budget. This cost figure is expected to rise to $\$ 26$ billion in 2010 [1]. Clearly, current renal replacement therapies need to produce better outcomes at a lower cost, or we will have to ration care.

Home dialysis, which may be better for many patients, is underutilized. In 1985, some 20000 patients were using home dialysis through Medicare. But budget cuts forced the elimination of paid assistants for home dialysis patients, and the number of home dialysis patients shrank to the low numbers we see today, as few as 2000 nationwide [1]. The typical regimen for patients on traditional dialysis consists of regular visits to a local dialysis center, 3 times a week for 3-4 hours at a time.

More importantly for patients, conventional in-center hemodialysis, thrice weekly, produces significant side effects. Cleaning the blood rapidly in 12 hours per week is an "unphysiologic" therapy [2,3]. Patients become short of breath, their blood pressures rise, and symptomatic uremic toxins rise between treatments. When these conditions are reversed rapidly by hemodialysis, the patients are often exhausted, nauseated, and hypotensive for 4 to 8 hours after dialysis. Patients actually feel good for a few days a week at best. Their physical fatigue is compounded by the psychological oppression of chronic illness and a treatment regimen in which they are passive recipients with little control over their own destiny.

\section{Home Nocturnal Dialysis}

In 1994, Drs Robert Uldall and Andreas Pierratos in Toronto, Canada, initiated a new form of dialysis by which patients were hemodialyzed at home at night while they slept [4]. They received 8 hours of hemodialysis 6 or 7 nights a week. The clinical results have been stunning and consistently reproducible. Patients on daily nocturnal hemodialysis (DNHD) feel "normal." They are not tired after dialysis. They have no restrictions on their fluids or diets. They have the daytime free, and many continue to work or return to work [4-8].

DNHD has been demonstrated to improve nutrition [7-12], reduce or eliminate the need for blood pressure medications with continued good blood pressures [8-10], and reduce the need for expensive medicines to treat anemia [4,8,9,14]. Sleep patterns improve [16-17] and so does cognition [13]. Left ventricular hypertrophy and other cardiac risk factors are reduced [17-22]. This is an especially important finding because most dialysis patients die of heart disease, not kidney failure. Phosphorus, calcium, and parathyroid hormone are normalized without dietary restrictions, phosphate binders, or expensive vitamin D analogues [23-25]. Finally, patients have fewer hospitalizations [4,26-30].

Several studies have demonstrated decreased total annual health care expenditures per DNHD patient, even though the actual cost of dialysis is higher [26-30]. One study of the Toronto patients showed an 18.2 percent decrease in total 
expenditures by DNHD patients when compared to similar in-center patients [29]. Although DNHD has higher expenditures for training, supplies, dialysis machines, and remote monitoring, DNHD patients still cost the health care system less.

And these benefits don't include intangibles like increased rates of rehabilitation and improved family life. For example, patients report improved libido which disappears in chronically and acutely ill people. DNHD patients report a return of libido, indicating that their individual physiologies have improved to the point that this human function returns.

The Rubin Dialysis Center has offered DNHD for 6 years [10]. It employs 37 people trained in DNHD and currently has 25 patients on nocturnal home hemodialysis. Patients have ranged in age from 27 to 76; one-third are female, and a quarter are African American and Hispanic. They live throughout upstate New York, and one travels 300 miles to the center's monthly clinic. Some live in apartments in inner cities; others live in rural trailer parks. The only extra expense our patients incur is an initial investment in plumbing adjacent to their bedrooms and the monthly cost of an extra phone line and Internet access. (The center monitors patients online over the Internet while they sleep) [31]. The only criteria for selection to this program are motivation, "reasonable" hearing, eyesight, dexterity, and memory. Thirty percent of the patients are diabetics with neuropathy and retinopathy.

\section{An Underutilized Therapy}

If DNHD's potential is so great, why do only 25 centers in the United States and Canada offer this modality to only 300 patients? Reimbursement for dialysis in the United States does not cover the cost of 6 treatments per week, thus discouraging dialysis units, most of which are operating on a very small margin, from taking the risk of this initially costly program. Savings by payers, patients, and society on medications, decreased hospitalizations, and improved rehabilitation are not passed on to dialysis providers, again reducing the incentive to offer this modality.

Finally there is appropriate skepticism of claims based on small numbers of patients. Given the experience with entitlements like dialysis, where the anticipated need was estimated to be only several thousand patients when passed by Congress in 1973, one has to respect the payers' and government's insistence on scientifically proven results in good studies with larger numbers of patients. This research is already in the formative stages. DNHD will be studied in the United States in a prospectively randomized controlled trial funded by National Institutes for Health and Centers for Medicaid Services beginning this fall [32].

DNHD is a win-win innovation for dialysis patients tired of feeling lousy, physicians frustrated by high morbidity and mortality, providers unable to staff or fund new units, and payers crippled by double-digit cost increases without improved outcomes.

\section{References}

1. US Renal Data System, USRDS 2003 Annual Data Report: Atlas of End-Stage Renal Disease in the United States. National Institute of Diabetes and Digestive and Kidney Diseases. Bethesda, MD: National Institutes of Health; 2003. Accessed Feb. 24, 2004. Google Scholar

2. Kjellstrand CM, Evans RL, Petersen RJ, Shideman JR, von Hartitzsch B, Buselmeier TJ. The "unphysiology" of dialysis: a major cause of dialysis side effects? Kidney Int Suppl. 1975;7:S30-S34. Google Scholar

3. Kooistra M, Vos P. Daily home hemodialysis: towards a more physiological treatment of patients with ESRD. Semin Dial. 1999;12:424-430. View Article Google Scholar

4. Pierratos A, Ouwendyk M, Francoeur R, et al. Nocturnal hemodialysis: three year experience. J Am Soc Nephrol. 1998;9:859-868. 
PubMed Google Scholar

5. Vos P. Quotidian dialysis: intradialytic and interdialytic symptoms. Presented at: The International Dialysis Conference; March 5, 2002; Tampa, Fla.

6. Kooistra M, Vos J, Koomans H, Vos P. Daily home hemodialysis in the Netherlands: effects on metabolic control, hemodynamics, and quality of life. Nephrol Dial Transplant. 1998;13:2853-2860.

View Article PubMed Google Scholar

7. McPhatter L, Lockridge R, Albert J, et al. Nightly home hemodialysis: improvement in nutrition and quality of life. Adv Renal Replace Ther. 1999;6:358-365.

View Article PubMed Google Scholar

8. Bender W, Torres M, Pittner J, Keller K. Nocturnal Home Hemodialysis (NHHD) results in dietary, medication, and laboratory changes. Perit Dial Int. 2000;20:(1) S101.

Google Scholar

9. Pierratos A. Nocturnal home haemodialysis: an update on a 5-year experience. Nephrol Dial Transplant. 1999;14:2835-2840.

View Article PubMed Google Scholar

10. Hoy C, Goldstein L, Meola S. Daily nocturnal hemodialysis. Perit Dial Int. 2000;20:S104. Google Scholar

11. Williams A, O'Sullivan D, Kumar R, McCarthy J. Improved solute clearance and PCR on slow nocturnal hemodialysis (SNHD). Perit Dial Int. 1998;18 Suppl 1:S-78.

Google Scholar

12. O'Sullivan D, McCarthy J, Kumar R, Williams A. Improved biochemical variables, nutrient intake, and hormonal factors in slow nocturnal hemodialysis: a pilot study. Mayo Clin Proc. 1998;73:1035-1045.

View Article PubMed Google Scholar

13. Pierratos A, Heslegrave RJ, Thornley K, et al. Nocturnal hemodialysis improves daytime cognitive function. $J$ Am Soc Nephrol. 1998;9:180A.

Google Scholar

14. Klarenbach SW, Heidenheim AP, Leitch R, Lindsay RM. Reduced requirement for erythropoietin with quotidian hemodialysis therapy. ASAIO J. 2002:48;57-61.

View Article PubMed Google Scholar

15. Pierratos A, Thornley K, Ouwendyk M, Francoeur R, Hanly P. Nocturnal hemodialysis improves sleep quality in patients with chronic renal failure. J Am Soc Nephrol. 1997;8:169A.

Google Scholar

16. Hanly PJ, Pierratos A. Improvement of sleep apnea in patients with chronic renal failure who undergo nocturnal hemodialysis. N Engl J Med. 2001;344:102-107.

View Article PubMed Google Scholar

17. Chan CT, Floras JS, Miller JA, Pierratos A. Improvement in left ventricular systolic function with longterm nocturnal hemodialysis. J Am Soc Nephrol. 2001;12:262A.

Google Scholar

18. Chan CT, Harvey PT, Picton P, et al. Short-term blood pressure, noradrenergic, and vascular effects of nocturnal home hemodialysis. Hypertension. 2003;42:925-31.

View Article PubMed Google Scholar

19. Chan CT, Miller J, Floras J, Pierratos A. Improvement in ejection fraction by nocturnal hemodialysis in endstage renal failure patients with coexisting heart failure. Nephrol Dial Transplant. 2002;17:1518-1521. View Article Google Scholar

20. Chan CT, Floras JS, Miller JA, Pierratos A. Regression of left ventricular hypertrophy after conversion to nocturnal hemodialysis. Kidney Int. 2002;61:2235-2239.

View Article PubMed Google Scholar

21. Friedman AN, Bostom AG, Selhub J, Levey AS, Rosenberg IH, Pierratos A. Nocturnal versus standard hemodialysis and plasma total homocystein levels. J Am Soc Nephrol. 2001;12:356A.

22. Raj D, Ouwendyk M, Francoeur R, Pierratos A. b 2 -Microglobulin kinetics in nocturnal haemodialysis. Nephrol Dial Transplant. 2000;15:58-64.

View Article PubMed Google Scholar

23. Lockridge R. Parathyroid disease and calcium-phosphorus product controlled with nightly home hemodialysis 
(NHHD). Perit Dial Int. 2000;20:S104.

Google Scholar

24. Mucsi I, Hercz G, Uldall R, Ouwendyk M, Francoeur R, Pierratos A. Control of serum phosphate without any phosphate binders in patients treated with nocturnal hemodialysis. Kidney Int. 1998;53:1399-1404.

View Article PubMed Google Scholar

25. Szabo T, Ouwendyk M, Pierratos A. Resolution of soft tissue calcification and improvement of bone density on nocturnal hemodialysis: a case report. Perit Dial Int. 2000;20:S109.

Google Scholar

26. Mohr P, Neumann P, Franco S, Marainen J, Lockridge R, Ting G. The quality of life and economic implications of daily dialysis. Policy Anal Brief H Ser. 1999;1:1-4.

PubMed Google Scholar

27. Mohr P, Neumann P, Franco S, Marainen J, Lockridge R, Ting G. The case for daily dialysis: its impact on costs and quality of life. Am J Kidney Dis. 2001;37:777-89.

View Article PubMed Google Scholar

28. Mohr P, Neumann P, Lockridge R, Ting G. The economic implications of daily hemodialysis. Perit Dial Int. 2000;20:S105.

Google Scholar

29. McFarlane PA, Pierratos A, Redelmeier DA. Cost savings of home nocturnal versus conventional in-center hemodialysis. Kidney Int. 2002;62:2216-22.

View Article PubMed Google Scholar

30. Lockridge R, Anderson H, Coffey L, et al. Nightly home hemodialysis in Lynchburg, Virginia: economic and logistic considerations. Semin Dial. 1999;12:440-447.

Google Scholar

31. Hoy CD. Remote monitoring of daily nocturnal hemodialysis. Hemodialysis International. 2001;5:8-12. View Article $\underline{\text { PubMed }}$ Google Scholar

32. National Center for Research Resources. Comparison of daily nocturnal hemodialysis with daily hemodialysis. Sponsored by National Center for Research Resources. Accessed February 13, 2004.

Christopher D. Hoy, MD, is the medical director of the home dialysis program and assistant medical director of the Rubin Dialysis Center, Saratoga Springs, New York.

The viewpoints expressed on this site are those of the authors and do not necessarily reflect the views and policies of the AMA.

(C) 2004 American Medical Association. All Rights Reserved. 